Journal of Agricultural Sciences
(Tarim Bilimleri Dergisi)

\title{
Effect of Adding Different Boron Sources to Diets Containing Low Calcium and Phosphorus on Some Bone Parameters of Weaned Akkaraman Lambs
}

\author{
Zehra SARIÇIÇEK ${ }^{\mathrm{a} *} \mathbb{D}$, Birgül YILDIRIM ${ }^{\mathrm{a}}$ \\ ${ }^{a}$ Ankara University, Faculty of Agriculture, Department of Animal Science 06110, Diskapi, Ankara, TURKEY \\ ARTICLE INFO \\ Research Article \\ Corresponding Author: B. Zehra SARIÇIÇEK, E-mail: zsaricicek@ankara.edu.tr \\ Received: 14 February 2020 / Revised: 10 April 2020 / Accepted: 03 June 2020 / Online: 04 September 2021
}

\section{ABSTRACT}

The aim of this study was to investigate the effect of addition of different boron sources (ulexide, colemanite, etibor-48) to diet containing low $\mathrm{Ca}$ $\mathrm{P}$ on bone parameters and bone strength in weaned lambs. 50 Akkaraman single male lambs weaned at 2.5 months of age were used. Lambs were divided into 5 groups. Groups were; positive control, negative control, supplementation with colemanite, supplementation with etibor-48, supplementation with ulexide. Roughage and concentrated feed was given twice in day. At the end of 90 days, 6 animals from each group were slaughtered. The weight, dry weight, length, width and ash levels of the femoral and tibial bones were significantly increased in added boron (B) sources groups compared to negative control. With the supplementation of the colemanite and ulexide to diets, the femoral and tibial Ca content was higher compared to negative control. The $\mathrm{P}$ content in the femoral bone increased in groups added of all boron sources than that in negative control, also in tibial $\mathrm{P}$ content in the colemanite and ulexide groups increased compared to negative control. The supplementation of all B sources had improved B levels and breaking strength of bones compared to controls.

Keywords: Bone Parameters, Colemanite, Etibor-48, Ulexide, Weaned Lambs

(C) Ankara University, Faculty of Agriculture

\section{Introduction}

There are wide variety mines in fertile land of Turkey. Turkey, with a total boron (B) reserves of 3.3 billion tons, with $73 \%$ share of the world's B reserves is in first place. The element B is present in various forms in environments such as soil, rock, ground, ocean water and atmosphere. There are about 230 kinds of B minerals in the world. More than 150 B minerals have been found in nature, including sodium, calcium and magnesium salts. At the present time, most of these varieties such as borax, tincal, colemanite, ulexite, probertite, pandermite, szyabelite, hydroboracite and kernite have commercial value. Tinkal $\left(\mathrm{Na}_{2} \mathrm{~B}_{4} \mathrm{O}_{7} .10 \mathrm{H}_{2} \mathrm{O}\right)$ and colemanite $\left(2 \mathrm{CaO} .3 \mathrm{~B}_{2} \mathrm{O}_{3} .5 \mathrm{H}_{2} \mathrm{O}\right)$ are the most available in terms of reserve and national economy in Turkey. Etibor-48 $\left(\mathrm{Na}_{2} \mathrm{~B}_{4} \mathrm{O}_{7} .5 \mathrm{H}_{2} \mathrm{O}\right)$ important deposits in Turkey Eskişehir in (24\%), while the colemanite beds Emet (Kütahya) and Bigadiç (Balikesir) located in the vicinity $(74 \%)$, ulexide $\left(\mathrm{NaCaB}_{5} \mathrm{O}_{9} .8 \mathrm{H}_{2} \mathrm{O}\right)$ is less, and if necessary, supplied as a byproduct. (Anonymous 2019).

$\mathrm{B}$ is an essential element found in most tissues in trace amounts. It plays an important role in bone formation, vitamin D metabolism, prevention of $\mathrm{Ca}$ and $\mathrm{Mg}$ losses and formation of estrogen and steroid hormones (Newnham 1994), and also metabolic enzyme activity (Devirian \& Volpe 2003). B is quickly absorbed by organisms, no stored in soft tissue, extracted by urine. Fat, muscle, heart, lung and intestine have lower levels of B but higher levels of bone (Moseman 1994). B plays a regulatory role in the metabolism of some minerals $(\mathrm{Ca}, \mathrm{P}, \mathrm{Mg}, \mathrm{Al}$ and $\mathrm{Mo}$ ). Bone development and strength are very important in breeding animals, especially long-walking animals. The bone length, diameter, weight and ash percent are very effective biometric measures for bone development. B has recently been used in rats and poultry feeds. Although B is one of the most important minerals for bone and joint health (Chapin et al. 1997; Schauss 2009), its deficiency is affected by the function and composition of some tissues such as skeleton, kidney and brain (Nielsen et al. 1991). Thus according to Hunt and Nielsen (1981) there is a relationship between bone structure and B, and calcification insufficiency in chicks leg deformation is improved by the addition of B. Similarly, Fry (2007) reported that positive relationship between boron and cholecalciferol. Some studies have shown that in chickens fed diets with insufficient B and cholecalciferol, dry weight of femoral and concentration of $\mathrm{Ca}, \mathrm{Cu}, \mathrm{Zn}$ are reduced (Bai \& Hunt (1996), additionally, B deficiency increases bone abnormalities (Hunt \& Nielsen 1981). Colemanite, ulexite and etibor-48 from B sources have not been studied in animal nutrition. B sources used in this experiment have never been tested in lambs before. Due to low B levels of grain cereals, the B contents of the concentrated feeds prepared with grain cereals are also low (WHO 1998). 
The hypothesis of the study is use of some boron sources in young ruminant diets containing low Ca and $\mathrm{P}$ may have a positive effect on bone development, thus, it is thought that boron sources such as colemanite, ulexite and etibor- 48 can be used as mineral additives in young ruminant diets and will contribute to the national economy. This study was conducted to determine the effects on some bone parameters and strength in weaned Akkaraman lambs of different boron sources supplementation to lamb ration including low level $\mathrm{Ca}$ and $\mathrm{P}$ and availability of this tree $\mathrm{B}$ sources in animal nutrition.

\section{Material and Methods}

\subsection{Animals and experimental treatments}

Femoral and tibial bones were obtained from slaughtered 50 head male Akkaraman lambs weaned at 2.5 monthly age, In the trial, concentrated feed including $17 \% \mathrm{CP}$ and $2800 \mathrm{kcal} \mathrm{kg}^{-1} \mathrm{ME}$ (Table 1) and dry meadow grass $(10.46 \% \mathrm{CP}$ and $1786 \mathrm{kcal}$ $\left.\mathrm{kg}^{-1} \mathrm{ME}\right)$ were used. Colemanite $\left(50.8 \%, 2 \mathrm{CaO}_{2} 3 \mathrm{~B}_{2} \mathrm{O}_{3} .5 \mathrm{H}_{2} \mathrm{O}\right)$, ulexide $\left(43 \%, \mathrm{NaCaB}_{5} \mathrm{O}_{9} .8 \mathrm{H}_{2} \mathrm{O}\right)$ and etibor- $48(48 \%$, $\mathrm{Na}_{2} \mathrm{~B}_{4} \mathrm{O}_{7} .5 \mathrm{H}_{2} \mathrm{O}$ ), were provided from Eti Maden Operations General Directorate.

Table 1- Ingredients and chemical composition of feedstufts

\begin{tabular}{lcc}
\hline Ingredients, \% & Positive control & Negative control \\
\hline Sunflower meal & 36.3 & 36.3 \\
Maize & 32 & 32 \\
Barley & 30 & 30 \\
Mineral mix. and Vit. (Premix)* & 0.1 & 0.1 \\
Limestone & 1.2 & - \\
Salt & 0.4 & 0.4 \\
\hline Analysed nutrients & & \\
\hline $\mathrm{CP}, \%$ & 17.00 & 17.00 \\
$\mathrm{Ca} \%$ & 1.36 & 0.74 \\
$\mathrm{P} \%$ & 0.59 & 0.45 \\
$\mathrm{~B}, \%$ & 0.0053 & 0.0053 \\
$\mathrm{ME}, \mathrm{kcal} \mathrm{kg}^{-1}$ & 2800 & 2800 \\
\hline
\end{tabular}

*; Primex, contained/kg Mn. 33 mg, Zn 25 mg, Fe 20 mg, Cu 6 mg, I 800 mg, Sel 66 mg and Co 160 mg; Vit-A 20.000 IU kg-1, Vit D3 3.000 IU kg-1, Vit E 25 $\mathrm{mg} \mathrm{kg}^{-1}, \mathrm{~K} 38.000 \mathrm{mg}$, B1 $4.000 \mathrm{mg}$, B2 $6.000 \mathrm{mg}$, B6 8.000mg, B112 $20 \mathrm{mg}$, Niacine $20.000 \mathrm{mg}$, Pantothenate 12.000.mg, Colin cloride 15.000.mg

\subsection{Determination of bone parameters}

Procedures of this experiment were approved by the Animal Experiments Local Ethics Committee (Decision No: 2013-4-13) of Ankara University, Ankara/Turkey.

At the beginning of experiment, were formulated standard diet without 3 different $\mathrm{B}$ sources (colemanite, ulexite and etibor48) and ration including low $\mathrm{Ca}$ and $\mathrm{P}$ (Table 1). Ca, $\mathrm{P}$ and $\mathrm{B}$ analyzes of the feeds used in the research (forage and feed stuffs in the structure of concentrate feeds) were made and considering B levels and purity degrees of B sources determined in feeds. Concentrates were prepared as the B levels $90 \mathrm{ppm} \mathrm{kg}^{-1} \mathrm{DM}$ (NRC 2007).

Treatment groups included: $\mathrm{Ca}$ and $\mathrm{P}$ standard level, (positive control); including low $\mathrm{Ca}$ and $\mathrm{P}$ and $\mathrm{B}$-free, (negative control); including low $\mathrm{Ca}$ and $\mathrm{P}$ and supplementing colemanite $90 \mathrm{ppm} \mathrm{kg}{ }^{-1} \mathrm{DM}$; including low $\mathrm{Ca}$ and $\mathrm{P}$ and supplementing ulexide 90 ppm kg-1 DM and including low Ca and P and supplementing etibor-48 90 ppm kg-1 DM (NRC 2007).

Fifty weaned male Akkaraman lambs of equal weight and age were randomly assigned to five treatment groups and 10 lambs in each group. Forage/concentrate feed ratio was prepared as 60/40. Daily feed requirement of lambs was calculated according to NRC (2007) recommendations, the feed amount was adjusted as percentage of live weight by weekly. Forage was provided ad libitum, and concentrate feed was given separately in two meals, morning (8.00 am) and noon (14.00 pm) at $90^{\text {th }}$ day of trial, six lambs from each groups were chosen/selected randomly and slaughtered. Right tibial and femoral bones were separated to determine some bone parameters of slaughtered lambs. Bones were soaked in hot water, and cleared from tissues, and then stored for $12 \mathrm{~h}$ at $4{ }^{\circ} \mathrm{C}$, and analysed the following day. Bones were weighted on a sensitive balance $(0.001 \mathrm{mg})$ and then their length and diameters were measured with a digital caliper (Tresna, USA). After leaving from bones marrow and oil, they were dried at $105^{\circ} \mathrm{C}$ for $24 \mathrm{~h}$ and re-weighed to determined dry weight. The bone breaking strength were determined by three point bending test with $500 \mathrm{~kg}$ load cell on (TA-HD Plus Texture Analyser, UK) and a probe with adjustable distance was used for the measurement. The bones were broken horizontally from their long axes. Dried fat-free bones were broken by a cutting tool after cleaning from interior tissues for ash analysis and ground, and after ashed at $610{ }^{\circ} \mathrm{C}$ for $24 \mathrm{~h}$ in a muffle furnace (Protherm, Turkey) and \% ash were determined. Femoral and tibial ash samples were weighed $(0.5 \mathrm{~g})$ and transferred into porcelain crucible. After adding of nitric acid-hydrocloric acid, burned at $180{ }^{\circ} \mathrm{C}$ for $30 \mathrm{~min}$. in microwave (Cem-Mars5) 175 PSI, and filtered through paper filters without ash into $100 \mathrm{~mL}$ plastic bottles for mineral analysis (Ca, $\mathrm{P}$ and $\mathrm{B}$ ), completed to $100 \mathrm{~mL}$ with 
distilled water. Then mineral matters in ash were read by ICP (Optima 2100 DV ICP / OES, PERKIN ELMER) at suitable wavelength (Boss \& Fredeen 2004).

\subsection{Statistical analysis}

The data were analyzed by one-way analysis of variance. To evaluate the structure of the data Kolmogorov-Smirnov one sample test was used for normality assumption and Levene test was used to examine the homosceasticidy (Önder 2018), results showed that all traits had normal distribution and variances were equal $(\mathrm{P}>0.05)$. Duncan's multiple comparison test was used to compare the means with significance level of 0.05 (Genç \& Soysal 2018). SPSS package program was used to analyse the data (SPSS 2002).

\section{Results}

\subsection{Bones parameters}

The effect of addition of different B sources on weight, dry weight, length, width and ash values of right tibial and femoral bones of weaned Akkaraman lambs is given in Table 2. As seen, the weight of right femoral bone of Akkaraman lambs was the highest in $\mathrm{B}$ groups compared to negative control $(\mathrm{P}<0.05)$. While there was no difference between $\mathrm{B}$ treatment groups, there were determined significant differences in between $\mathrm{B}$ groups and control groups $(\mathrm{P}<0.05)$.

Table 2- The effect on femoral and tibial bone parameters of different boron sources

\begin{tabular}{llllllll}
\hline \multirow{2}{*}{ Parameters } & Bone & $\begin{array}{l}\text { Positive } \\
\text { control }\end{array}$ & $\begin{array}{l}\text { Negative } \\
\text { control }\end{array}$ & Colemanite & Ulexide & Etibor-48 & $P$ \\
\hline \multirow{2}{*}{ Weight, g } & Femoral & $29.95 \pm 0.155^{\mathrm{a}}$ & $26.10 \pm 0.122^{\mathrm{c}}$ & $28.85 \pm 0.227^{\mathrm{b}}$ & $28.30 \pm 0.210^{\mathrm{b}}$ & $28.23 \pm 0.445^{\mathrm{b}}$ & 0.436 \\
& Tibial & $40.12 \pm 0.164^{\mathrm{a}}$ & $37.58 \pm 0.262^{\mathrm{c}}$ & $39.78 \pm 0.105^{\mathrm{a}}$ & $39.82 \pm 0.238^{\mathrm{a}}$ & $38.73 \pm 0.155^{\mathrm{b}}$ & 0.292 \\
Dry weight, g & Femoral & $20.12 \pm 0.179^{\mathrm{a}}$ & $16.87 \pm 0.578^{\mathrm{c}}$ & $20.67 \pm 1.026^{\mathrm{a}}$ & $20.15 \pm 0.198^{\mathrm{a}}$ & $18.39 \pm 0.290^{\mathrm{b}}$ & 0.138 \\
Length, & Tibial & $29.34 \pm 1.044^{\mathrm{a}}$ & $26.82 \pm 0.021^{\mathrm{c}}$ & $29.48 \pm 1.053^{\mathrm{a}}$ & $29.82 \pm 1.011^{\mathrm{a}}$ & $27.10 \pm 0.027^{\mathrm{b}}$ & 0.177 \\
cm & Femoral & $17.92 \pm 0.021^{\mathrm{a}}$ & $16.35 \pm 0.036^{\mathrm{b}}$ & $17.90 \pm 0.024^{\mathrm{a}}$ & $17.85 \pm 0.025^{\mathrm{a}}$ & $16.99 \pm 0.027^{\mathrm{ab}}$ & 0.165 \\
\multirow{2}{*}{ Width cm } & Tibial & $19.43 \pm 0.441^{\mathrm{a}}$ & $18.10 \pm 0.031^{\mathrm{b}}$ & $19.27 \pm 0.096^{\mathrm{a}}$ & $18.98 \pm 0.102^{\mathrm{a}}$ & $19.33 \pm 0.228^{\mathrm{a}}$ & 0.184 \\
& Femoral & $2.39 \pm 0.423^{\mathrm{a}}$ & $1.96 \pm 0.521^{\mathrm{b}}$ & $2.32 \pm 0.233^{\mathrm{a}}$ & $2.38 \pm 0.425^{\mathrm{a}}$ & $2.28 \pm 0.327^{\mathrm{a}}$ & 0.457 \\
\multirow{2}{*}{ ash,\% } & Tibial & $2.27 \pm 0.623^{\mathrm{a}}$ & $1.97 \pm 0.447^{\mathrm{b}}$ & $2.13 \pm 0.282^{\mathrm{a}}$ & $2.22 \pm 0.326^{\mathrm{a}}$ & $2.11 \pm 0.135^{\mathrm{a}}$ & 0.419 \\
& Femoral & $57.91 \pm 0.389^{\mathrm{a}}$ & $54.88 \pm 0.270^{\mathrm{b}}$ & $57.05 \pm 0.228^{\mathrm{a}}$ & $56.87 \pm 0.393^{\mathrm{a}}$ & $56.99 \pm 0.340^{\mathrm{a}}$ & 0.315 \\
& Tibial & $63.07 \pm 0.309^{\mathrm{a}}$ & $58.76 \pm 0.614^{\mathrm{b}}$ & $61.76 \pm 0.836^{\mathrm{a}}$ & $63.12 \pm 0.495^{\mathrm{a}}$ & $62.62 \pm 0.518^{\mathrm{a}}$ & 0.386 \\
\hline
\end{tabular}

a,b,c; Means with different superscript within same line significantly differ $(\mathrm{P}<0.05)$

The tibial weight reported in this study ranged from $37.58 \mathrm{~g}$ to $40.12 \mathrm{~g}$. The lowest tibial weight was determined in negative control $(\mathrm{P}<0.05)$, There were no significantly different between positive control with colemanite and ulexide. Also Etibor-48 was significantly lower than the positive control and the other $\mathrm{B}$ groups $(\mathrm{P}<0.05)$.

Dry weight of the femoral and tibial ranged from 16.87 to $20.67 \mathrm{~g}$ and 26.82 to $29.82 \mathrm{~g}$ respectively, in present study. Dry weight of femoral and tibial bones was significantly higher in boron groups according to negative control $(\mathrm{P}<0.05)$. The best results among $\mathrm{B}$ sources were found in colemanite and ulexide groups $(\mathrm{P}<0.05)$. There were no significantly different between positive control with colemanite and ulexide.

Length of femoral and tibial ranged from 16.35 to $17.92 \mathrm{~cm}$ and 18.10 to $19.43 \mathrm{~cm}$ respectively. There was no significant difference between positive control and B treatment groups in terms of tibial and femoral length, whereas the lowest length was determined in negative control with low $\mathrm{Ca}$ and $\mathrm{P}$ content $(\mathrm{P}<0.05)$.

The width and ash content of femoral and tibial bones increased in all B groups compared to negative control $(\mathrm{P}<0.05)$. There was no significant differences between B sources and positive control.

\subsection{Bone mineral contents}

The effect on bone mineral composition of different B sources addition to Akkaraman lambs diets is presented in Table 3. It can be seen that the dietary supplementation of colemanite and ulexide compared to negative control improved Ca level of femoral and tibial bones $(\mathrm{P}<0.05)$. There was no significant differences between positive control and colemanite group. Ca level was significantly higher in colemanite added group than other $\mathrm{B}$ groups $(\mathrm{P}<0.05)$. The results showed that $\mathrm{B}$ sources positively affected femoral $\mathrm{P}$ levels compared to negative control $(\mathrm{P}<0.05)$. There was no significant difference among $\mathrm{B}$ sources for $\mathrm{P}$ content. Colemanite and ulexide supplementation to diet increased $\mathrm{P}$ level of tibial bone compared to negative control. There was no difference between etibor-48 and negative control. On the other hand, the highest $\mathrm{P}$ level in femoral and tibial bones were found in positive control $(\mathrm{P}<0.05)$. Mg content of bones was not affected by the addition of the B sources. B content of femoral and tibial bones was significantly higher in treatment groups using B sources compared to the control groups $(\mathrm{P}<0.05)$, but no 
significant difference was found between B sources. Supplementation of B sources has shown positive effect on B levels of femoral and tibial bones $(\mathrm{P}<0.05)$.

Table 3- The effect on mineral composition femoral and tibial bones of different B sources, DM\%

\begin{tabular}{cccccccc}
\hline \multicolumn{2}{l}{ Parameters } & Positive control & Negative control & Colemanite & Ulexide & Etibor-48 & $P$ \\
\hline \multirow{2}{*}{ Ca } & Femoral & $25.15 \pm 1.079^{\mathrm{a}}$ & $13.01 \pm 2.235^{\mathrm{c}}$ & $24.53 \pm 1.241^{\mathrm{a}}$ & $20.606 \pm 1.471^{\mathrm{b}}$ & $15.91 \pm 1.868^{\mathrm{bc}}$ & 0.130 \\
& Tibial & $27.82 \pm 0.287^{\mathrm{a}}$ & $23.23 \pm 0.122^{\mathrm{c}}$ & $27.75 \pm 0.715^{\mathrm{a}}$ & $25.10 \pm 0.837^{\mathrm{b}}$ & $23.72 \pm 0.019^{\mathrm{c}}$ & 0.195 \\
& Femoral & $14.95 \pm 0.700^{\mathrm{a}}$ & $7.24 \pm 4.615^{\mathrm{c}}$ & $10.76 \pm 8.129^{\mathrm{b}}$ & $11.08 \pm 6.242^{\mathrm{b}}$ & $10.26 \pm 9.246^{\mathrm{b}}$ & 0.136 \\
$\mathrm{P}$ & Tibial & $19.29 \pm 1.194^{\mathrm{a}}$ & $13.54 \pm 1.361^{\mathrm{c}}$ & $15.08 \pm 1.097^{\mathrm{b}}$ & $15.82 \pm 1.858^{\mathrm{b}}$ & $14.82 \pm 1.752^{\mathrm{bc}}$ & 0.431 \\
& Femoral & $0.19 \pm 1.086$ & $0.18 \pm 1.574$ & $0.17 \pm 2.874$ & $0.17 \pm 2.158$ & $0.18 \pm 1.580$ & 0.000 \\
$\mathrm{Mg}$ & Tibial & $0.21 \pm 1.315$ & $0.22 \pm 1.322$ & $0.21 \pm 1.523$ & $0.22 \pm 0.985$ & $0.22 \pm 0.948$ & 0.000 \\
& Femoral & $0.607 \pm 0.090^{\mathrm{b}}$ & $0.543 \pm 0.057^{\mathrm{c}}$ & $0.648 \pm 0.380^{\mathrm{a}}$ & $0.644 \pm 0.035^{\mathrm{a}}$ & $0.651 \pm 0.046^{\mathrm{a}}$ & 0.336 \\
$\mathrm{~B}$ & Tibial & $0.721 \pm 0.049^{\mathrm{b}}$ & $0.717 \pm 0.015^{\mathrm{b}}$ & $0.762 \pm 0.009^{\mathrm{a}}$ & $0.793 \pm 0.027^{\mathrm{a}}$ & $0.807 \pm 0.003^{\mathrm{a}}$ & 0.432 \\
\hline
\end{tabular}

a,b,c; Means with different superscript within same line significantly differ $(\mathrm{P}<0.05)$

\subsection{Bone breaking strength}

The effect of addition of different B sources on bone breaking strength of weaned Akkaraman lambs is given in Table 4. The addition of $\mathrm{B}$ sources to diet containing low $\mathrm{Ca}$ and $\mathrm{P}$ significantly increased the breaking strength of femoral bone of Akkaraman lambs compared to control groups $(\mathrm{P}<0.05)$ (Table 4). No difference in breaking strength was observed among ulexide and etibor-48 groups. The addition of colemanite to diets was lower than effect on breaking strength compare to other B treatment groups in femoral and tibial bones. Breaking strength in tibial bone increased by supplementation ulexide and etibor-48 ( $\mathrm{P}<0.05)$. On the other hand, the lowest breaking strength was determined in negative control including low Ca and $\mathrm{P}$ for both bones. No significant difference in breaking strength was observed between colemanite and positive control.

Table 4- The effect of different boron sources on fracture strength of femoral and tibial bones

\begin{tabular}{lllllll}
\hline Parameters & Positive control & Negative control & Colemanite & Ulexide & Etibor-48 \\
\hline Femoral $(\mathrm{N})$ & $781.69 \pm 14.725^{\mathrm{c}}$ & $720.34 \pm 13.702^{\mathrm{d}}$ & $822.50 \pm 11.366^{\mathrm{b}}$ & $937.15 \pm 15.964^{\mathrm{a}}$ & $970.10 \pm 17.542^{\mathrm{a}}$ & 0.156 \\
Distance,cm & $3.84 \pm 0.229$ & $4.28 \pm 0.165$ & $4.07 \pm 0.278$ & $5.75 \pm 0.326$ & $5.49 \pm 0.437$ \\
Tibial (N) & $891.62 \pm 12.606^{\mathrm{b}}$ & $743.24 \pm 22.497^{\mathrm{c}}$ & $889.19 \pm 12.658^{\mathrm{b}}$ & $997.47 \pm 14.863^{\mathrm{a}}$ & $1001.01 \pm 15.584^{\mathrm{a}}$ & 0.141 \\
Distance, $\mathrm{cm}^{\mathrm{C}}$ & $7.58 \pm 0.326$ & $8.03 \pm 0.330$ & $8.00 \pm 0.148$ & $7.07 \pm 0.747$ & $8.29 \pm 0.595$ & 0.000 \\
\hline
\end{tabular}

$\mathrm{N}$; Newton, a,b,c; Means with different superscript within same line significantly differ $(\mathrm{P}<0.05), * * ;(\mathrm{P}<0.05)$

\section{Discussions}

\subsection{Bone parameters}

No studies were conducted on the use of colemanite, ulexide and etibor-48 in animal nutrition, especially in ruminant nutrition, whereas all animal nutrition studies were related to boric acid.

In this study, B sources had a positive effect on weight of femoral and tibial bones compared to negative control group including low $\mathrm{Ca}$ and $\mathrm{P}$. Thus, the addition of $\mathrm{B}$ to the diet containing low $\mathrm{Ca}$ and $\mathrm{P}$ improved femoral weight. While no difference was found between the B sources in terms of femoral bone weight, colemanite and ulexite gave better results on tibial weight than etibor-48. Kurtoğlu et al. (2005) reported that the addition of 5 and $25 \mathrm{mg} \mathrm{kg}^{-1} \mathrm{DM}$ B to the poultry diet with sufficient and inadequate vitamin D3 content did not affect tibial weight. In this study, the addition of B sources significantly increased dry weight of femoral and tibial bones compared to negative control. This increase is a result of compensating the mineral deficiency by adding $\mathrm{B}$ sources to diet since there was $\mathrm{Ca}$ and $\mathrm{P}$ low levels in negative control. The best results in terms of dry weight were determined in colemanite and ulexite groups. Bai \& Hunt (1996), reported that femoral dry weight, Ca, Cu and $\mathrm{Zn}$ concentration in femoral decreased in chicks fed with rations insufficient B and cholecalcipherol. In this study, B sources increased the length of femoral and tibial bones compared to negative control. These findings are similar to findings of Devirian \& Volpe (2003), indicating that addition of B in rats and chicks increases bone length. Also, Hunt et al. (1994) reported that B provides maturation in the developmental regions of long bones. In our study, there was no significant difference in bone length between B added groups and positive control including standard $\mathrm{Ca}$ and $\mathrm{P}$. The addition of $\mathrm{B}$ sources to diet positively affected width of femoral and tibial bones compared to low $\mathrm{Ca}$ and $\mathrm{P}$ content group. No study was found to be compared with these results. The effect of B sources on ash level of femoral and tibial bones was positive compared to negative control. But, there was no difference between positive control and treatment groups. It was stated that addition of B to diet increased bone ash (Qin \& Klandorf 1991; Wilson \& Ruszler 1997), whereas did not affect (Fassani et al. 2004; Y1ldiz et al. 2011). Differences in research results may be 
attributed to differences in B sources and animal species. The presence of Ca and Na minerals in the structure of B sources used in this study may be the cause of the increase in the rate of bone ash. On the other hand, Kheiri \& Rahmani (2006) reported that tibial ash was affected by $\mathrm{Ca}$ and $\mathrm{P}$ change, and also according to Edwards (1987), supplementation of B to chick diet increased tibial bone ash percentage and reduced the incidence of tibial dyschondroplasia.

\subsection{Bone mineral content}

In femoral and tibial bones, the lowest $\mathrm{Ca}$ level was determined in negative control containing low $\mathrm{Ca}$ and $\mathrm{P}$, but higher $\mathrm{Ca}$ content was observed in positive control. colemanite and ulexite from B sources significantly increased Ca levels compared to negative control group. The highest $\mathrm{Ca}$ content among the treatment groups was determined in colemanite added group in femoral and tibial. The presence of $\mathrm{Ca}$ in the structure of colemanite and $\mathrm{Ca}$ and $\mathrm{Na}$ in the structure of ulexite from treatment groups may be reason for the increase in bone Ca content. According to Brown et al. (1989), excessed B level in diet increases the amount of $\mathrm{Ca}$ retained in the body. Browning et al. (2012), stated that broiler chicks fed with low $\mathrm{Ca} / \mathrm{P}$ diet had more Ca accumulation in their bones than those of fed with high Ca / P diet. Contrary to results of this study, Fassani et al. (2004) expressed that addition of B to poultry feed did not affect bone Ca levels. In this study, the addition of B sources had a positive effect on the P level of bones compared to negative control. These results were supported by Bozkurt et al. (2009) who reported that bone Ca and $\mathrm{P}$ content, with supplementation of boric acid 30 and $60 \mathrm{ppm}$ to poultry diets including low $\mathrm{Ca}$ and $\mathrm{P}$, raised to control group including standard $\mathrm{Ca}$ and $\mathrm{P}$ level. $\mathrm{Ca}$ and $\mathrm{P}$ are essential for skeletal structure and development in growing young ruminants. Ca and $\mathrm{P}$ are form of hydroxyapatite in bone tissue (Van den Top 2009). Ca and P deficiency can leads to rickets in young growing animals.

In this study, to give good results in diet including low $\mathrm{Ca}$ and $\mathrm{P}$ of $\mathrm{B}$ sources may be explained with resistance against to Ca and $\mathrm{P}$ deficiency. The addition of $\mathrm{B}$ sources has no positive effect on $\mathrm{Mg}$ content of femoral and tibial bone. Some studies has been reported that $\mathrm{B}$ has a regulatory effect on mineral metabolism, especially on $\mathrm{Ca}, \mathrm{P}$ and $\mathrm{Mg}$ metabolism, and has a positive effect on bone development and mineralization (Nielsen et al. 1988; Chapin et al. 1998; Armstrong et al. 2000; Miyamoto et al. 2000). In our study, B content of femoral and tibial bones increased significantly in treatment groups compared to control groups. The increase in B level is a result of adding B sources to diet. In some studies in poultry, as the amount of B in feed increases, the amount of B in bones increases (Wilson \& Ruszler 1997; Wilson \& Ruszler 1998; Y1ldiz et al. 2011), supporting the findings of this study.

\subsection{Bone breaking strength}

In present study, addition of B sources to diets significantly increased breaking strength of femoral and tibial bones of Akkaraman lambs compared to control groups. The lowest breaking strength was determined in negative control. In this group, the Ca and $\mathrm{P}$ level in diet is lower than standard level, which may have caused a decrease in breaking strength. The findings of study are supported by Armstrong \& Spears (2001). Who states that B together with Ca and P contributes to the maintenance of bone strength. Similarly, Schauss (2009) also states that B is one of the most important minerals in bone and joint health. Nielsen (2004) reported that bone strength is reduced in broilers and pigs fed with low B diet but high levels of B supplementation increase bone strength in chicks. Rossi et al. (1993), reported that $5 \mathrm{mg} \mathrm{kg}^{-1} \mathrm{~B}$ addition to diets, tibial fracture resistance in male broiler increases. Breaking strength of bones is very important for bone strength in young animals, especially in breeding animals and animals that have to walk long distance.

\section{Conclusions}

Adding different B sources to growing Akkaraman lamb diets positively affected weight, dry weight, length, width, ash and mineral content of femoral and tibial bone compared to negative control group. The addition of colemanite, ulexite and etibor48 to diet positively affected breaking strength and B content of the femur and tibia bones compared to both the positive and negative control groups. It can be used as mineral additive colemanite, ulexite and etibor-48 in Akkaraman lambs diets especially including low $\mathrm{Ca}$ and $\mathrm{P}$.

\section{Acknowledgements}

This study was supported by Ministry of Agriculture and Forestry. (Project number TAGEM-13 / ARGE-28). The authors are thankful to the Director, for providing the necessary facilities to conduct the present research work. The TAGEM Directors, Republic Of Turkey Ministry Of Agriculture And Forestry-TAGEM

\section{References}

Anonymous (2019). Boron in Turkey, Etimaden, http://www.etimaden.gov.tr/turkiyede-bor

Armstrong T A \& Spears J W (2001). Effect of dietary boron on growth performance, calcium and phosphorus metabolism and bone mechanical properties in growing barrows. Journal of Animal Science 79(12): 3120-3127 doi.org/10.2527/2001.79123120x 
Armstrong T A, Spears J W, Crenshaw T D \& Nielsen F H (2000). Boron supplementation of a semipurified diet for weanling pigs 1mproves feed efficiency and bone strength characteristics and alters plasma lipid metabolites. Journal of Nutrition 130(10): 2575-2581 doi: $10.1093 / \mathrm{jn} / 130.10 .2575$.

Bai Y \& Hunt C D (1996). Dietary boron (B) increases serum antibody concentrations in rats immunized with heat-killed mycobacterium tuberculosis. Federation of American Societies for Experimental Biology 10, A819

Boss C B. \& Fredeen K J 2004. Concepts, instrumentation and techniques in inductively coupled plasma optical emission spectrometry. Shelton, Perkin Elmer, Third Edition, pp. 76

Bozkurt M, Küçükyılmaz K, Çatlı A U, Çınar M, Çabuk M, Mızrak C \& Bintaş E (2009). Effects of boron supplementation on some blood, bone and fecal parameters in broiler feeds containing different levels of calcium and phosphorus 6. Animal Science Congress 24-26 June, Erzurum-Turkey

Brown T F, Mccormick M E, Morris D R \& Zeringue L K (1989). Effects of dietary boron on mineral balance in sheep. Nutrition Research 9(5):503-512

Browning L C, Antipatis C \& Cowieson A J (2012). The interactive effects of vitamin D, phytase, calcium and phosphorus in broiler performance and skeletal integrity. Australian Poultry Science Symposium 23: 81-84

Chapin R E, Ku W W, Kenney M A, McCoy H, Gladen B, Wine R N, Wilson R \& Elwell M (1997). The effects of dietary boron on bone strength in rats Fundamental and Applied Toxicology 35(2): 205-215

Chapin R E, Ku W W, Kenney M A \& McCoy H (1998). The effects of dietary boric acid on bone strength in rats. Biological Trace Element Research 66: 395-399

Devirian T A \& Volpe S L (2003). The physiological effects of dietary boron. Critical Reviews in Food Science and Nutrition 43(2): 219-231 doi: 10.1080/10408690390826491

Edwards H M Jr (1989). The effect of dietary cholecalciferol, 25-hydroxycholecalciferol and 1,25-dmydroxycholecalciferol on the development of tibial dyschondroplasia in broiler chickens in the absence and presence of disulfiram. Journal of Nutrition 119: 647-652

Fassani E J, Bertechini A G, Brito J A G, Kato R K, Fialho E T \& Geraldo A (2004). Boron supplementation in broiler diets. Brazilian Journal of Poultry Science 6(6): 213-217 doi.org/10.1590/S1516-635X2004000400004

Fry R S (2007). Effect of dietary boron on 1mmune function and disease resistance to bovine herpesvirus type1 in growing steers. Msc.Thesis[u1], North Carolina, USA (unpublished), http://www.lib.ncsu.edu/resolver/1840.16/329

Genç S \& Soysal M I (2018). Parametric and nonparametric Post Hoc tests. Black Sea Journal of Engineering and Science 1(1): 18-27

Kheiri F \& Rahmani H R (2006). The effect of reducing calcium and phosphorous on broiler performance. International Journal of Poultry Science 5(1):22-25 doi:10.3923/jips.2006.22.25

Kurtoğlu V, Coşkun B, Şeker E, Balevi T \& Çetingül I S (2005). Effects of boron supplementation on performance and some serum biochemical parameters in laying hens. Revue deMedicine Veterinary 153(12): 823-828

Hunt C D \& Nielsen F H (1981). Interaction between boron and cholecalciferol in the chicks. Australian Academy of Science 597-600

Hunt C D, Herbel J L \& Nielsen F H (1994). Dietary boron modifies the effects of vitamin d3 nutrition on indices of energy substrate utilisation and mineral metabolism in the chick. Journal Bone Mineral Research 9(2): 171-182

Miyamoto S, Sutoh M, Shimoto A, Yamazaki S, Nishimura K, Yonezawa C, Matsue H \& Hoshi M (2000). Determination of boron in animal by reactor neutron induced prompt gamma-ray analysis. Journal of Radioanalytical and Nuclear Chemistry 244(2): 307-309

Moseman R F (1994). Chemical disposition of boron in animals and humans, Environ Health Perspect 102(7): 113-117

Newnham R E (1994). Essentially of boron for healthy bones and joints. Environ Health Perspect 102(7): 83-5

Nielsen F H (2004). Dietary fat composition modifies the effect of boron on bone characteristics and plasma lipids in rats. Biofactors 20(3): 161-171

Nielsen F H, Shuler T R, Zimmerman T J \& Uthus E O (1988). Dietary magnesium, manganese and boron affect the response of rats to high dietary aluminum. Magnesium 7(3): 133-147

Nielsen F H, Mullen L M \& Nielsen E J (1991). Dietary boron affects blood cell counts and hemoglobin concentrations in humans. The Journal of Trace Element in Experimental Medicine 4: 211-223

NRC (2007). Nutrient requirement of small ruminant: sheep, goats, cervids, and new world camelids. National Academy Press 384

Önder H (2018). Nonparametric statistical methods used in biological experiments. Black Sea Journal of Engineer Science 1(1): 1-6

Qin X \& Klandorf H (1991). Effects of dietary boron supplementation on egg production, shell quality, and calcium metabolism in aged broiler breeder hens. Poultry Science 70 (10): 2131-2138

Rossi A F, Miles R D, Damron B L \& Flunker L K (1993). Effect of dietary boron supplementation on broilers. Poultry Science 72(11): 21242130

Schauss A G (2009). Under-appreciated mineral enhances cognition, bone and joint health. http://www.vrp.com/articles.aspx?ProdID=2151

SPSS 2002. SPSS for Windows release 11.0 versions, Copyright SPSS inc. NY

Wilson J H \& Ruszler P L (1997). Effects of boron on growing pullets. Biological Trace Elements Research 56(3):287-294

Wilson J H \& Ruszler P L (1998). Long term effects of boron on layer bone strength and production parameters. British Poultry Science 39 (1):11-15

WHO (1998). International programme on chemical safety environmental health criteria 204, Ohio, USA: 1-201

Van den Top A M (2009). Reviews on the mineral provision in ruminants (I): Calcium Metabolism and Requirements In Ruminants. VB documentatierapport $\mathrm{Nr} 45$

Yildiz A O, Olgun O \& Cufadar Y (2011). Effects of boron supplementation to diet on performance and boron deposition in broilers. Archiva Zootechnica 14(3): 32-36 